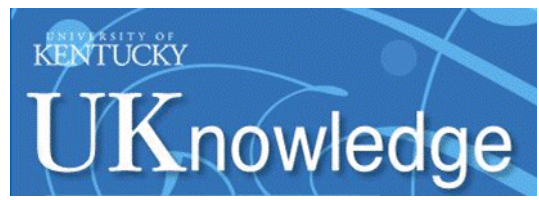

Journal of Natural Resources \&

Environmental Law

Volume 8

Issue 2 Journal of Natural Resources \&

Environmental Law, Volume 8, Issue 2

Article 4

January 1993

\title{
UNCED and the Development of International Environmental Law
}

Peter H. Sand

World Bank Legal Department

Follow this and additional works at: https://uknowledge.uky.edu/jnrel

Part of the Environmental Law Commons, and the International Law Commons

Right click to open a feedback form in a new tab to let us know how this document benefits you.

\section{Recommended Citation}

Sand, Peter H. (1993) "UNCED and the Development of International Environmental Law," Journal of Natural Resources \& Environmental Law: Vol. 8: Iss. 2, Article 4.

Available at: https://uknowledge.uky.edu/jnrel/vol8/iss2/4

This Article is brought to you for free and open access by the Law Journals at UKnowledge. It has been accepted for inclusion in Journal of Natural Resources \& Environmental Law by an authorized editor of UKnowledge. For more information, please contact UKnowledge@lsv.uky.edu. 


\title{
UNCED and the Development of International Environmental Law
}

\author{
Peter H. Sand*
}

The United Nations Conference on Environment and Development (UNCED) held in Rio de Janeiro, Brazil, from June 3 to 14,1992 , was the largest UN Conference ever held, with more than 30,000 participants from 176 countries, including 103 heads of state or government assembled for the concluding "Earth Summit." In terms of diplomatic history, the Rio meeting is thus comparable to major multilateral peace conferences, such as the 1815 Vienna Congress or the 1919 Versailles Conference. The peace and security perspective may indeed not be far-fetched: in his opening statement to the UNCED Preparatory Committee in March 1990, the Secretary General had already pointed out that "in this case, the security of our planet and our species is at risk. Surely this must be seen as the ultimate security risk which calls for the ultimate security alliance."2 Post-Rio appraisals would confirm that assessment. ${ }^{3}$

* Legal Adviser, Environmental Affairs, World Bank Legal Department, Washington, DC; formerly Principal Legal Officer, United Nations Conference on Environment and Development (UNCED). Views and opinions expressed are those of the author and should not be attributed to the institutions with which he is or was associated.

This work is printed as it appears in 3 YearbooK of INTERNATIONAL ENVIRONMENTAL LAw 3-17 (1992).

1 Report of the United Nations Conference on Environment and Development (Rio de Janeiro, 3-14 June 1992) UN Doc. A/CONF.151/26/Rev. 1, 2 vols. (1992); complete directory of registered participants in WHO IS WHO AT THE EARTH SUMmT, RiO DE JANEIRo 1992, (H.J. Keller, ed., Visionlink 1992).

2 Maurice F. Strong, Statement to the Organizational Session of the Preparatory Committee, March 5, 1990. See P.H. Sand, International Law on the Agenda of the United Nations Conference on Environment and Development: Towards Global Environmental Security?, 60 NoRDIC J. INT'L L. 5-18 (1991); and 2 Y.B. INT'L ENV. L. 42530 (1991).

3 See James Gustave Speth, A Post Rio Compact, Foreion Poucy, No. 88 (Fall 1992), pp. 145-161. The outcome of UNCED has been analysed in a large number of studies, most of which tend to declare the conference a qualified success; e.g., see Peter M. Haas, Marc A. Levy and Edward A. Parson, Appraising the Earth Summit: How Should We Judge UNCED's Success?, ENVIRonment, vol. 34, No, 8 (October 1992), pp. 6-15, 26-36; Richard N. Gardner, Negotiating Survival: Four Priorities after Rio, (Council on Foreign Relations, New York, 1992); Lothar Brock, Nord-Süd Kontroversen 
As might be expected from a diplomatic conference, Rio had its share of diplomatic problems-starting from controversies over where it should be held, ${ }^{4}$ who should and who should not attend, ${ }^{5}$ and whether it should be postponed or cancelled altogether. ${ }^{6}$ In the end, these problems were resolved with little more than anecdotal impact. The basic question remains, however, whether the Conference accomplished its substantive objectives, and to what extent it satisfied the high-perhaps excessiveexpectations of participants and observers.

The present analysis will not attempt to answer this question for the full range of the UNCED agenda, as defined by the broad conference mandate of UN General Assembly Resolution 44/228.' Instead, it will be confined to the specific legal-institutional matters assigned to the Conference, in particular its Working Group III. ${ }^{8}$

in der internationalen Umweltpolitik: Von der taktischen Verknüpfung zur Integration von Umwelt und Entwicklung?, HSFK-REPORT 7/1992 (Hessian Foundation for Peace and Conflict Research: Frankfurt, September 1992), 39 pp.; and Asian-African Legal Consultative Committee, United Nations Conference on Environment and Development: Outcome and the Follow-up, AALCC/UNGA/92/2 (October 1992), 131.

- In anticipation of the North-South compromises that were to mark UNCED (see text at note 74 below), Brazil was preferred over potential other venues such as Sweden (where the 20th anniversary of the 1972 UN Stockholm Conference on the Human Environment could have been celebrated), though balanced by the appointment of Canadian Maurice Strong as Secretary-General.

s Austrian President Waldheim, who had planned to attend, was persuaded not to go. US President Bush, who had planned not to attend, was finally persuaded to go. When the planned attendance of Japanese Prime Minister Miyazawa was prevented by last-minute political events at home, an attempt to have his prepared speech delivered to the Earth Summit by videotape ran into UN protocol objections. Instead of EC Environment Commissioner Ripa di Meana, who refused to attend, EC Commission President Delors attended, following an ad hoc amendment of the rules of procedure by the UN General Assembly granting him near-equal treatment with heads of government (Resolutions 46/469-471 of April 13, 1992). Haiti was represented by exiled President Aristide. As to the representation of Yugoslavia, the credentials of the SerbiaMontenegro delegation were accepted despite reservations recorded by the USA and the EC (A/CONF.151/26, vol. IV, paras. 7 and 14).

- The original dates of June 1-12 were changed by Resolution 46/468 of the UN General Assembly in April 1992 in order to facilitate attendance by Islamic statesmen after the Ramadan religious holidays. An internal political scandal implicating Brazil's President Collor de Mello erupted one week before the Conference hosted and chaired by him, and three months later led to his impeachment and eventual resignation.

- Resolution 44/228 of December 22, 1989; see also Resolutions 45/211 of December 21, 1990; 46/168 of December 19, 1991; and 46/468 of April 13, 1992.

- Working Group III on legal, institutional and other related matters was established by the UNCED Preparatory Committee at its second session in March 1991, with terms of reference specified in PrepCom decision 2/3, UN Doc. A/46/48, vol. I, p. 28, 
The Rio Conference may be seen as another incremental step in the evolution of international environmental law, adding further material to the growing body of legal norms in this fieldwhich by now is well-documented in the Register of International Treaties and Other Agreements in the Field of the Environment, regularly updated by the United Nations Environment Programme (UNEP), ${ }^{9}$ and in a wide range of official and unofficial collections of relevant texts. ${ }^{10}$ In fact, the direct impact of UNCED on this ongoing evolutionary process was best illustrated by a UNEP-sponsored meeting of Senior Government Officials Expert in Environmental Law, held in Rio de Janeiro from October 30 to November 2, 1991. "Convened with a man-

text in 2 Y.B. INT'L ENv. L. 426 n.11 (1991). Negotiations in the Working Group (chaired by former Czechoslovakian Environment Minister Moldan) were mainly conducted in open-ended sub-groups moderated by diplomats from India, Malaysia, Norway, and the Philippines. After the end of the fourth PrepCom session in New York (MarchApril 1992), a few remaining issues were resolved in the Main Committee at the Rio Conference (under PrepCom chairman Koh from Singapore), through contact groups led by Egyptian Ambassador El-Arabi and Malaysian Ambassador Razali. A summary account of the day-to-day proceedings of the Preparatory Committee (including Working Group III) and the Rio Conference is available in the EARTH SUmmit Bulletin issued during the sessions by the International Institute for Sustainable Development ' (IISD). See also C. Tinker, Institutional Developments: The United Nations Conference on Environment and Development, 2 Y.B. INT'L ENv. L 68-71 (1991); A.O. Adede, Interutational Environmental Law from Stockholm to Rio: An Overview of Past Lessons and Future Challenges, 22 ENv. PoL'Y \& L. 88-105 (1992); Nicholas C. Yost, Rio and the Road Beyond, Environmental Law (Quarterly Newsletter of the American Bar Association's Standing Committee on Environmental Law), vol. 11, No. 4 (Summer 1992) pp. 1-6; and The Role of Law in the 1992 United Nations Conference on Environment and Development (American Bar Association: Standing Committee on Environmental Law, 1992).

9 The 1991 edition of the Register (UNEP/GC.16/Inf.4, currently under revision for the 1993 Governing Council session) contains information on 152 multilateral treaties.

") Including the UNEP Reference Series 3, Selected Multilateral Treaties iN THE FIEID of the ENvironment, vol. 1 (A.C. Kiss ed., 1983), 525 pp., and vol. 2 (I. Rummel-Bulska \& S. Osafo ed., 1991), 527 pp.; the 5 trilingual loose-leaf volumes of International Envirommental law: Multilateral Treaties (W.E. Burhenne \& O. Seidel eds., 1974-1992); the 30 volumes of International Protection of the Environment: Treaties and Related Documents (B. Rüster \& B. Simma eds. 1975-1983), updated since 1989 by 3 loose-leaf volumes; International Environmental Law: Prmaray Materials (M.R. Molitor ed., 1991), 571 pp.; International Environmental Law: Basic Instruments and References (E.B. Weiss, P.C. Szasz \& D.B. Magraw eds., 1992), 749 pp.; World Treaties for the Protection of the Environment (T. Scovazki \& T. Treves eds. 1992), $720 \mathrm{pp}$; Basic Documents of International Envronmental Law (H. Hohmann ed., 1992), 3 vols., 1850 pp.

"See the report of the meeting, UNEP/Env.Law/2/3 (1991); see I. RummelBulska, United Nations Environment Programme (UNEP), 2 Y.B. INT'L ENv. L. 382391 (1991). 
date to revise the long-term Montevideo Programme for the Development and Periodic Review of Environmental Law originally formulated in $1981,{ }^{12}$ the 1991 meeting reached an impasse because most of the delegates refused to make any programmatic decisions on this subject prior to the 1992 "Earth Summit." While one of the reasons for this refusal was the overriding broader mandate of UNCED for both environmental and developmental matters, their main concern was the perceived role of UNCED as charting the course of future environmental lawmaking. In the end, UNEP had to convene a resumed session in Nairobi, in September 1992, in order to finalize its revision of the Montevideo Programme on the basis of the UNCED outcomes. ${ }^{13}$

\section{HARD OR SOFT RULES?}

It has become habitual to categorize international environmental provisions in terms of "hard law" and "soft law," depending on whether or not they meet formal treaty criteria. ${ }^{14}$ By this yardstick, the normative products of UNCED-the "Rio Instruments"15 - are readily identified: on the one hand, the United Nations Framework Convention on Climate Change and the Convention on Biological Diversity, both prepared by parallel intergovernmental negotiating committees and opened for

12 UNEP/GC.10/5/Add.2, Annex, Ch.II (1981), adopted by UNEP Governing Council decision 10/21 on May 31, 1982, and endorsed by UN General Assembly Resolution 37/217; see P.H. Sand, Environmental Law in the United Nations Environment Programme, in: The Future of the International Law of the ENvironment (R.J. Dupuy ed., 1985) p. 51; and C.A. Petsonk, The Role of the United Nations Environment Programme (UNEP) in the Development of International Environmental Law, 5 AM. U.J. INT'L L. \& PoI'Y 351-391, at 364 (1990).

${ }^{13}$ See the report of the meeting, UNEP/Env.Law/2-2/L.2 (1992), Annex I: Pr., gramme for the Development and Periodic Review of Environmental Law.

14 See P.M. Dupuy, Soft Law and the International Law of the Environment, 12 Mich. J. InT'L L. $420-435$ (1991); G. Handl, Environmental Security and Global Change: The Challenge to International Law, 1 Y.B. INT'L ENV. L. 3-33 (1990), at 7-8; and generally C.M. Chinkin, The Challenge of Soft Law: Development and Change in International Law, 138 INT'L \& CoMP. L. Q. 850-866 (1989); and H.E. Chodosh, Neither Treaty nor Custom: The Emergence of Declaratory International Law, 26 TEXAs INT'L L. J. 87-124 (1991).

${ }_{15}$ Texts in 31 I.L.M. 814-887 (1992); 22 ENVTL. PoL'y \& L. 251, 268 (1992); and The Earth Sumat (S. Johnson ed., London 1991), 576 pp. On the negotiations leading up to the Rio Conference, see T. Goldman \& S. Hajost, Global Climate, 2 Y.B. INT'L Evv. L. 111-115 (1991); C. de Klemm, Nature Conservation: Biological Diversity and Natural Areas, 2 Y.B. INT'L ENv. L. 201-204 (1991); and G. Biggs, Latin American Perspectives on UNCED, 2 Y.B. INT'L ENV. L. $431-448$ (1991). See also note 8 above. 
signature at Rio as formal multilateral treaties; on the other hand, the Rio Declaration on Environment and Development (consisting of 27 principles) and the separate set of 15 Principles for a Global Consensus on the Management, Conservation and Sustainable Development of All Types of Forests, both adopted by the Conference and subsequently endorsed by the United Nations General Assembly as declaratory and exhortatory acts. ${ }^{16}$

In practical terms, the distinction is somewhat less clear-cut. The conventions will, of course, become legally binding only three months after they obtain the necessary minimum number of ratifications; with the Climate Change Convention having scored 9 of 50 and the Biodiversity Convention 7 of 30 ratifications as of December 31, 1992, that is unlikely to happen before mid-1993..$^{17}$ Any substantive analysis of the two conventions will have to concede that-save as to institutional provisions-the obligations they impose on Contracting Parties for the time being are largely aspirational, and hence may appear no less "soft" than those formulated in the two declaratory instruments. ${ }^{18}$ This is at least partly due to the fact that both conventions make use of the "framework approach" that has become a favorite technique of international environmental lawmaking: rather than attempting to codify a sectoral regime once and for all, they start out by defining its normative scope in very general language, to be specified only later in a dynamic sequence of subsequent "protocols." 19

It is worth recalling that this framework technique made its first appearance in environmental treaty drafting in 1974, when the Spanish delegation proposed a "convenio-marco" with separate protocols to protect the marine environment of the Medi-

16 UNGA Resolution 47/190 of December 22, 1992, endorsing the principles proclaimed (paragraph 2) and urging governments and organizations to take the necessary action for follow-up (paragraph 4).

1 See the criteria for entry into force of the Climate Change Convention (Article 23) and the Biodiversity Convention (Article 36); see also D. Bodansky, Managing Climate Change, and F. Burhenne-Guilmin \& S. Casey-Lefkowitz, The Convention on Biological Diversity: A Hard-Won Global Achievement, 3 Y.B. INT'L ENv. L. 43-59, 60-74 (1992).

${ }^{18}$ E.g., compare the principles of the Rio Declaration and those proclaimed in Article 3 of the Climate Change Convention, which overlap and actually influenced each other during the parallel drafting process.

19 Handl (note 14 above), at 5-7; and T. Gehring, International Environmental Regimes: Dynamic Sectoral Legal Systems, 1 Y.B. INT'L ENv. L. 35-56 (1990). 
terranean. ${ }^{20}$ After its adoption in the 1976 Barcelona Convention and its protocols, ${ }^{21}$ the technique was applied and further developed by UNEP in a series of agreements for other regional seas, $^{22}$ wildlife conservation ${ }^{23}$ and protection of the ozone layer. ${ }^{24}$ Other examples include the UN/ECE Conventions on Longrange Transboundary Air Pollution ${ }^{25}$ and on the Protection and Use of Transboundary Watercourses and International Lakes. ${ }^{26}$ Both the Climate Change Convention (Article 17) and the Biodiversity Convention (Article 28) anticipate the future development of protocols along these lines, which-without requiring participation by all Parties-allow for the progressive specification of commitments among those Parties ready and able to move ahead.

The Rio conventions are thus essential building blocks for a future climate and biodiversity regime; they are "intermediate agreements" open to adjustment and supplementary regulation as required. ${ }^{27}$ Unlike the 1982 UN Convention on the Law of the Sea ${ }^{28}$ however, they are not genuine global codifications. The oceans regime that emerged from UNCLOS III may be defined as a self-contained new international order for the marine sector, allocating rights and responsibilities of States over the available ocean space and affirming a comprehensive resource-oriented approach that embraces all potential uses and users of the resource. By contrast, the 1992 UN Framework

20 At the Third Diplomatic Conference of Mediterranean States on the Law of the Sea (Athens, March 1974): see J.A. de Yturriaga (ed.), LA ACTUAI REVISION DEL Derecho DEI MAR: UNA PERSPECTIVA ESPANOLA, vol. II/2, 521-525 (Madrid 1974). The equivalent French term "convention-cadre" has also been used by the Council of Europe, in the European Outline Convention on Transfrontier Cooperation Between Territorial Communities or Authorities (Madrid, May 21, 1980), 20 I.L.M. 315 (1981).

21 15 I.L.M. 290 (1976), 19 I.L.M. 869 (1980).

2 The 1978 Kuwait, 1981 Abidjan, 1981 Lima, 1982 Jeddah, 1983 Cartagena, 1985 Nairobi, and 1986 Noumea Conventions and their respective protocols, texts in P.H. Sand, Marine Envtronmental Law in the United Nations Envtronment Programme (London 1988).

2s The 1979 Bonn Convention on the Conservation of Migratory Species of Wild Animals, 19 I.L.M. 15 (1980), and its supplementary agreements for protected species. ${ }^{24}$ The 1985 Vienna Convention and its 1987 Montreal Protocol, 26 I.L.M. 1529, 1550 (1987).

25 18 I.L.M. 1442 (1979); and the protocols in 24 I.L.M. 484 (1985), 27 I.L.M. 707 (1988), 28 I.L.M. 214 (1989), 31 I.L.M. 573 (1992).

${ }^{26}$ Signed at Helsinki (March 17, 1992), text in 3 Y.B. INT'L ENv. L. (1992).

${ }^{27}$ See Gehring (note 19 above), and J.T. Mathews, Redefining Security, 68 ForEIGN AFF. 162, 176 (1989).

23 Signed at Montego Bay, December 10, 1982; 21 I.L.M. 1261 (1982). 
Convention on Climate Change is not a "Convention on the Law of the Air," as some had pretended it should be, at least until the Ottawa meeting in 1989.29 It does not even attempt to define or allocate sovereign rights over airspace, the vertical delimitation of which will continue to nourish legal debates in the UN Committee on the Peaceful Uses of Outer Space (COPUOS). The mandate of the Intergovernmental Negotiating Committee $^{30}$ was limited to protection against global warming risks and to the specific uses and misuses of the atmosphere affecting this issue; the mandate did not extend to a global regime of the atmosphere. Similarly, even a generous reading of the Convention on Biological Diversity will not elevate it to a global regime for the Earth's living resources. The crucial questions of intellectual property rights and of safety against the risks of biotechnology were deferred to future cooperation and possible protocols, ${ }^{31}$ although even the prospect of international regulation in this field proved too much for at least one country. ${ }^{32}$

Even the hard-fought compromise text of the Rio Declaration has been ranked as "intermediate" by as competent a commentator as Maurice Strong, when he suggested in his closing statement to the Conference that the Declaration "must continue to evolve towards what many of us hope will be an Earth Charter that could be finally sanctioned on the 50th anniversary of the United Nations in 1995." ${ }_{33}$ As it stands, the Declaration repre-

20 Protection of the Atmosphere: Statement of the International Meeting of Legal and Policy Experts, Ottawa, February 1989; see also J. Bruce, Law of the Air: A Conceptual Outline, 18 ENv. Por'y \& L. 5 (1988).

30 UN General Assembly Resolutions 45/212 of December 21, 1990; 46/169 of December 19, 1991; and 47/195 of December 23, 1992.

${ }^{31}$ Articles 16(5) and 19(3); see K. Miller \& C. Barber, Biodiversity After the Earth Summit: Prospects for the Convention on Biodiversity, NETwORK ' 92 No. 18 (Geneva: Centre for Our Common Future, July 1992) p. 5.

${ }^{32}$ See the US declaration made at the UNEP Conference for the Adoption of the Agreed Text of the Convention on Biological Diversity (Nairobi, May 22, 1992), 31 I.L.M. 848 (1992).

33 M.F. Strong, Statement to the Plenary on June 14, 1992; 22 ENv. Pol'y \& L. 243 (1992). See H. Mann. The Rio Declaration, [1992] ASIL, Procendngs 405-411, for an appraisal of the PrepCom negotiations, reflecting the disappointment of a number of participants over the "missed historic opportunity" for an Earth Charter. Indirectly, paragraph 39.5 of Agenda 21 acknowledges unfinished business in this regard, by reserving the option of future "examination of the feasibility of elaborating general rights and obligations of States, as appropriate, in the field of sustainable development, as provided by General Assembly Resolution 44/228." 
sents a delicate balance of policy goals supported by developed and developing countries, reflected mainly in two sets of key principles without which the compromise would have collapsed: on the one hand, public participation, the "precautionary approach," and the "polluter pays" maxim (Principles 10,15 and 16) considered as essential by the developed countries; on the other hand, the "right to development," poverty alleviation and the recognition of "common but differentiated responsibilities" (Principles 3, 5 and 7) on which the developing countries insisted. ${ }^{34}$ While the Declaration's preamble reaffirms the 1972 Stockholm Declaration on the Human Environment ${ }^{35}$ in its entirety, Principle 2 actually modifies the wording of Principle 21 of the Stockholm text by adding the words "and developmental" to the assertion of national environmental policies for resource exploitation. The nuance is perhaps less significant in substance-resource use being inherently "developmental" anyway ${ }^{36}$-than in the process of law-making, considering that Principle 21 of the Stockholm Declaration is widely considered as having become a rule of customary international law. ${ }^{37}$ Even though the Rio Declaration could hardly be deemed to have brought about an "instant amendment" of customary law, the UNCED experience highlights the need to clarify processes of change and adjustment for "hard" and "soft" rules alike.

\section{Non-law or Pre-law OUtcomes?}

The very success of soft-law instruments in guiding the evolution of contemporary international environmental law has also produced a backlash effect: governments have become wary

34 The compromise wording of the controversial third sentence of principle 7 was actually based on a statement of the OECD Ministerial Meeting on Environment and Development, Paris, December 3, 1991; 2 Y.B. INT'z ENv. L. 529 (1991), disk doc. 24, para. 5. The US delegation, while joining consensus on the Declaration at Rio, submitted an interpretative statement expressing reservations on principles $3,7,12$ and 23 ( $A$ / CONF.151/26, vol. IV, paragraph 16).

311 I.L.M. 1416 (1972); see L.B. Sohn, The Stockholm Declaration on the Human Environment, 14 HARv. INT'L L.J. 423-515 (1973).

${ }^{36}$ Contrary to a common misconception, the Stockholm Declaration was not limited to "environmental" concerns and did address development issues, especially in principles 8 and 11; see Sohn (note 35 above), at 464-466, 469.

37 E.g., see A: Kiss \& D. Shelton, International Environmental Law 106-107 (1991); N. Fitzwanga, The 1972 United Nations Declaration on the Human Enylromment and Its Jurmical Frontiers: Dissertative Treatise on International EnVironmental Law (Nottingham 1991); and Mann (note 33 above) at 410. 
of attempts at formulating reciprocal principles even when couched in non-mandatory terms, well knowing that "soft" declarations or recommendations have a tendency to harden over time and to come back to haunt their authors. ${ }^{38}$ Hence, the tactical desire to guard against legal connotations of the terms used (as illustrated by the US statement of interpretation after the Rio Declaration was adopted)" or against eventual "legalization" of pre-legal terms (as illustrated by the US position on "concepts or principles significant for the future of environmental law" during the UNEP follow-up meeting in September 1992). ${ }^{40}$

Similar tactical concerns explain the curious warning label ("non-legally binding") affixed to the Rio Forest Principles. ${ }^{41}$ Originally envisaged as the blueprint for a binding treaty, ${ }^{42}$ "elements for a global consensus" are all that remained after extensive and often acrimonious negotiations within and outside the UNCED Preparatory Committee, marked by strong resistance from Third-World timber-producing countries against mandatory multilateral regulation in this field. One basic reason for their resistance was the perceived threat to sovereignty from a treaty regime, in view of unabashed proposals from developed countries for global intervention by UN "green helmets" in

3 For pertinent examples see T.M. Franck \& E. Weasband, Word Pourtics: Verbal Strategy Amono the Superpowers (New York: Oxford University Press, 1971).

${ }^{39}$ See note 34 above.

* Report (note 13 above), paragraphs 22 and 23. In view of strong opposition mainly from the US delegation, a proposed list of concepts and principles for further development was deleted from the draft UNEP programme document and merely reproduced in the body of the meeting report, as follows: "precautionary approach, polluterpays principle, common concern of mankind, inter-generational equity, new and equitable global partnership, common but differentiated responsibility, public participation, and market-based approaches."

4 Non-legally binding authoritative statement of principles for a global consensus on the management, conservation and sustainable development of all types of forests, A/CONF.151/26, vol.III, Annex III. On the earlier negotiations see J. Cameron, Forests, 2 Y.B. INT'L ENv. L. 213-215 (1991). See also note 74 below.

42 E.g., see the proposal for an International Convention on Conservation and Development of Forests submitted in the Food and Agriculture Organization of the United Nations (FAO) Committee on Forestry in September 1990 (COFO-90/3/a), and eventually deferred to UNCED in the 99th FAO Council Session in June 1991 (FAO doc. CL99/PV/14); and the proposal for a World Forest Agreement/ Convention, by the Global Legislators' Organization for a Balanced Environment (GLOBE) in January 1991. A Japanese proposal for an International Charter for the World's Forests was submitted in the International Tropical Timber Organization in 1991. Further intergovernmental initiatives, led by Sweden, are currently under consideration. 
pursuit of an alleged droit d'ingérence écologique, ${ }^{43}$ or more subtle calls for the international community to assume its "joint responsibility for areas whose ecological significance far surpasses that of the countries in which they are situated geographically: the Amazon region, the Himalayas, Antarctica, certain seas, and areas constituting part of the 'common heritage of mankind." 44 Not unpredictably, the reaction of the Amazon region's military commander, Brazilian General Sotero Vaz, is also on record: "I will tell you, and tell you clearly: if those babacas try to come here, we will hit them like gurerrillas." 45

The deadlock resulting from this confrontation of extreme views prevented agreement even on the question of future treaty negotiations, save for consideration of "the need for and the feasibility of all kinds of appropriate internationally agreed arrangements to promote international cooperation" on forestry. ${ }^{46}$ Paradoxically, therefore, the elaborate set of forest principles produced by the Rio Conference represents less substantial progress than the single paragraph (12.40) of its Agenda 21 calling for a new Convention to Combat Desertification to be finalized by 1994-which has since been heeded by a UN General Assembly resolution getting the process underway. ${ }^{47}$

By the same token, several new "conference diplomacy" initiatives launched under the oceans chapter of Agenda 21 (with regard to small island States, straddling fish stocks, and land-

43 See R. Cans, L'ingerence ecologique, LE MondE of November 28, 1991, at 8; C. Cans, L'ingerence verte: assistance ou intervention?, Les CAHIERS DU FUTUR: ENvironNement- Developpement No. 2 (August 1992) 12-16; and U. Kulke, Grenzenlose Einmischung, Natur No. 12 (December 1991) 34-35. But see also H.M. De Lemos, Amazonia: In Defense of Brazil's Sovereignty, 14 FletCHER Forum of WorLd Afrairs 301-312 (1990).

4 J. Pronk, A New International Ecological Order, 14 InteRnationale Spectator 728-732 (1991), at 729-730. Mr. Pronk, Netherlands Minister for Development Cooperation, was one of the chief negotiators at the Rio Conference and subsequently cochaired the UN Secretary General's high-level advisory panel on UNCED follow-up; see UN Press Release SG/A/503 of August 12, 1992.

4s Interview with E. Ribeiro on August 28, 1991, translation in Crosscurrents: AN INDEPENDENT NGO NEWSPAPER FOR UNCED No. 10 (September 1991) at 12.

to Agenda 21, paragraph 11.12(e). See N. Yost (note 8 above), at 5-6. The final text of Agenda 21 is reproduced in the report of the Rio Conference (note 1 above) as Annex II, in volumes I-III.

4 UNGA Resolution 47/188 of December 22, 1992, establishing an intergovernmental negotiating committee for the elaboration of an international convention to combat desertification in those countries experiencing serious drought and/or desertification, particularly in Africa. The first meetings are scheduled to be held in New York (January 25-29) and in Nairobi (March 29 to April 8, 1993). 
based marine pollution $)^{48}$ may well turn out to have more tangible-albeit deferred-legal outcomes than some of the provisions ostensibly calling for the development of further international law (such as Principle 13 of the Rio Declaration, with regard to liability and compensation for transboundary harm). 49

In a few instances, the Rio Conference chose to delegate specific legal topics to future action in other competent fora: e.g., in the International Atomic Energy Agency (IAEA) with regard to preparation of a nuclear safety convention; ${ }^{50}$ and in the Sixth Committee of the UN General Assembly with regard to environmental protection in times of armed conflict, ${ }^{51}$ deliberately side-stepping the wider issue of "ecological crimes" as originally raised in the UNCED Preparatory Committee. ${ }^{32}$ As regards the issue of potential conflicts between environment and

49 Agenda 21, paragraphs 17.26, 17.49 and 17.130, followed by UNGA Resolutions $47 / 189$ and $47 / 192$, deciding to convene a global conference on the sustainable development of small developing island States (Barbados, April 1994) and a conference on straddling and highly migratory fish stocks (New York, July 1993), respectively. The 1992 UNEP Programme for the Development and Periodic Review of Environmental Law (note 13 above) calls on the UNEP Governing Council to convene another conference on the protection of the marine environment from land-based activities.

49 The Declaration's call for cooperation "in an expeditious and more determined manner" conveys a certain amount of frustration with the lack of progress in this field in spite of exhortations in principle 22 of the Stockholm Declaration. Contrary to earlier expectations - e.g. G. Hafner, Civil Liability and Other Forms of Transnational Accountability, 2 Y.B. INT'ı ENv. L. 91, at 98 (1991) - the relevant chapters of Agenda 21 make no provision for follow-up on this topic. However, the 1992 UNEP Programme for the Development and Periodic Review of Environmental Law (note 13 above) includes "legal and administrative mechanisms for the prevention and redress of pollution and other environmental damage."

so Agenda 21, paragraph 39.7. See N. Pelzer, Nuclear Energy, 2 Y.B. INI'l ENv. L. 150-155 (1991), at 153-154.

"Agenda 21, paragraph 39.6, stipulating that the specific competence and role of the International Committee of the Red Cross (ICRC) are to be taken into account. However, in its report to the General Assembly (A/47/328, July 1992) the ICRC emphasized the need for better compliance with existing international rules in this field, rather than the development of new instruments as advocated by others; e.g., see G. Plant, Environmental Protection and the law of War: A "Fifth Geneva" Convention on the Protection of the Environment in Times of Armed Conflict (London 1992).

s2 By the EC delegation, prompted by a joint declaration of the Russian and German Environment Ministers (Moscow, June 3, 1991) calling for "international condemnation of crimes against the environment," and for inclusion of the topic in the UNCED agenda. After further debate of the issue in the UN General Assembly and at PrepCom 4, the Main Committee of the Rio Conference eventually decided to follow proposals by the USA and several developing countries and restricted the scope of paragraph 39.6 in Agenda 21 to times of armed conflict. 
trade law, the Rio Conference was unable to move beyond the status quo reflected in identical terms in both chapter 2 and chapter 39 of Agenda 21, which were taken verbatim from the earlier Cartagena Commitment of the UN Conference on Trade and Development (UNCTAD). ${ }^{53}$ Attempts to include this issue in the future work plan of UNEP, at the subsequent Nairobi meeting in September 1992, met with solid opposition both from the USA and from a number of developing countries and had to be deferred; ;4 as a result, the forum competent to elaborate the UNCTAD-based "principles and rules" on trade and environment identified in Agenda 21 remains unspecified, and-de facto or faute de mieux - now is the "Group on Environmental Measures and International Trade" of the General Agreement on Tariffs and Trade (GATT) ${ }^{\text {ss }}$.

Reference should also be made to the "alternative treaties" prepared at Rio by the International NGO Forum, in the context of the parallel independent-sector "Global Forum ' 92 "' attended by more than 8000 non-governmental groups and organizations. ${ }^{56}$ Not intended as legally binding instruments, nor as a substitute for the important simultaneous input of NGOs to the official UNCED process and other ongoing efforts at international environmental law-making, ${ }^{57}$ the "alternative treaties" served mainly as a focus of civic interaction between NGOs in the joint articulation of goals and action plans. Significantly,

"UNCTAD, 8th session (Cartagena, February 1992), text in 22 ENV. Pol'y \& L. 134 (1992), reproduced in paragraphs 2.22(i) and 39.3(d) of Agenda 21.

s Report (note 13 above), paragraph 24 and annex II; "environment and trade" was, however, retained as one of the topics for future consideration among "additional subjects" ".

ss The Group (originally established in 1971 but not convened until 1991) has held a total of seven meetings in Geneva during 1992, dealing with (1) trade provisions in existing multilateral environmental agreements, (2) multilateral transparency of national environmental regulations likely to have trade effects, and (3) trade effects of new packaging and labelling requirements aimed at protecting the environment. For background see F. Weiss, GATT, 2 Y.B. INT'l ENV. L. 346-353 (1991), at 351-352.

s6 P. Padbury, NGOs Sign Alternative Treaties at the ' 92 Global Forum, NETwORK ' 92 No. 18 (Geneva: Centre for Our Common Future, June-July 1992) p. 17; see also E. Parson, P.M. Haas \& M.A. Levy, A Summary of the Major Documents Signed at the Earth Summit and the Global Forum, 34 EnVIRoNment No. 8 (October 1992) 12, at 35-36; and NGO Treaties, E \& D FmE vol. II No. 1 (New York: United Nations NonGovernmental Liaison Service, December 1992).

5 E.g., the Draft Covenant on Environmental Conservation and Sustainable Use of Natural Resources prepared by an ad hoc NGO working group of experts under the aegis of the Commission on Environmental Law of the World Conservation Union (IUCN); Draft 5 (1992). See also note 60 below. 
though, instead of delivering final texts as conference products, the Forum decided to turn them into "open documents" for continuous development through electronic networking. ${ }^{58}$ The preference, here again, was for an open-ended process of institutional learning, in close parallel to what Jessica Mathews has called the new "fluid" model of environmental regimes" that best describes the Rio outcomes.

\section{UN REFORM OR UN BYPASS?}

The UNCED preparatory process also generated high hopes for global institutional reform, reflected in a wide array of bold new proposals for restructuring the United Nations system to cope with the environment/development problematique and for improving the established patterns of international decision-making and governance generally. ${ }^{60}$ As illustrated by the UNCED Secretariat's compilation of submissions from governments, intergovernmental and non-governmental organizations, ${ }^{61}$ the spectrum ranged from ambitious visions of world government (including a global environmental legislature, an Ecological Security Council, and an international environment tribunal) to new methods of standard-setting, enforcement and dispute prevention.

s8 The computer conference on which the 46 draft "treaties" are available is managed by a Uruguay-based communications network (NGONet), with follow-up promoted by regional focal points; list in NETWORK No. 20 (Geneva: Centre for Our Common Future, October 1992), p. 14.

99 J.T. Mathews, Redefining Security, 68 ForeIGN AfFArRs 162-177 (1989), at 176.

so Among the numerous pre-Rio appraisals see P.S. ThaChER, BaCKGRound to Institutional Options for Management of the Global Environment and Commons (World Federation of United Nations Associations: Project on Global Security and Risk Management, March 1991); J. MacNeILl, P. Winsemius \& T. YakUshII, Beyond INTERDEPENDENCE (Oxford University Press, 1991); R. Falk, Toward a World Order Respectful of the Global Ecosystem, 19 Boston College Env. AfFalrs L. Rev. 711-724 (1992); H.F. French, After the Earth Summit: The Future of Environmental Governance, Woridwatch Paper No. 107 (Worldwatch Institute, March 1992); L.A. Krmball, Forging International Agrfement: Strengthening Intergovernmental INSTITUTIONS for Environment and Development (World Resources Institute, April 1992); G. Palmer, New Ways to Make Environmental Law, 86 AM. J. INI't L. 259-283 (1992); G. Palmer, An International Regime for Environmental Protection, 42 WASH. U.J. Urban \& CONTEMP. L. 5-19 (1992), and comments by A.S. Miller, G. Gelfand \& A.D. Tarlock, at 21-53; and the NGO "Hague Recommendations" summarized in BiodrversITY and INTERNational Law: THE EFfectiveness of INTERNational ENVIRONMENTAL LAW (S. Bilderbeek ed., Netherlands National Committee for IUCN, 1992), at 124-156.

${ }^{61}$ Institutional Proposals, UNCED Doc. A/CONF.151/PC/102 (1992). 
As negotiations during PrepCom 3 (Geneva, August 1991) and PrepCom 4 (New York, March 1992) began to focus on arrangements for UNCED follow-up, it soon became clear that there was no majority support for radical innovations, let alone utopia. The recommendations for institutions and law-making that finally emerged (mainly under chapters 38 and 39 of Agenda 21), eventually to be confirmed and specified by the UN General Assembly and the Secretary General in December 1992, ${ }^{62}$ were of more modest dimensions:

- at the intergovernmental level, a new 53-member ECOSOC Commission on Sustainable Development, mainly to carry out public audits of the performance of governments and international organizations in their implementation and financing of Agenda 21;

- at the secretariat level, a new UN Department for Policy Coordination and Sustainable Development headed by an Undersecretary-General at New York headquarters, and an Inter-Agency Committee on Sustainable Development under the existing UN Administrative Committee on Coordination; and

- at the expert level, a High-level Advisory Board of eminent persons, reporting to the Secretary General and through him to the Commission.

In addition to these UN bodies, UNCED witnessed the emergence of two further institutions likely to have a major impact also on the future development of international environmental law:

- a restructured Global Environment Facility (GEF), ${ }^{63}$ already designated to operate the "financial mechanisms" of the

62 Report of the UN Secretary-General on Institutional Arrangements to Follow Up UNCED, UN Doc. A/47/593 and Add.1 (1992); UN Press Releases SG/A/516 and SG/A/520 of December 4, 1992; and UN General Assembly Resolution 47/191 of December 22, 1992. See also L.A. Kimball, Toward Global Environmental Management: The Institutional Setting, 3 Y.B. INT'L ENv. L. (1992), 18-42; and General Assembly Creates CSD, Network No. 21 (Geneva: Centre for Our Common Future, November 1992), at 1,4. For a summary account of the UN General Assembly negotiations see the The Earth Negotlations Bulletin, vol. 3 Nos. 1-3 (November-December 1992) issued by the International Institute for Sustainable Development, as successor to the EARTH Summat BuLLFTIN (note 8 above).

63 On the establishment of the GEF see W.P. Ofosu-Amaah, C.E. Di Leva \& R.U. Osterwoldt, World Bank, 2 Y.B. INT'L ENv. L. 403, at 407 (1991); Center for International Environmental Law-US, Multilateral Lending Activities: Development Assistance and Sustainable Development, 2 Y.B. INT'L ENv. L. 233, at 235-237 (1991); see also I.F.I. Shihata, The World Bank and the Environment: $A$ Legal Perspective, 16 MARYIAND J. INT'L L. \& TrAde, 1-42 at 31-36 (1992). 
two Rio Conventions on an interim (and possibly permanent) basis, and expected to serve as funding channel also for other components of Agenda 21, including future legal instruments such as the proposed 1994 Desertification Convention. Restructuring of the GEF (under the auspices of the World Bank, in cooperation with UNDP and UNEP) for the post-1993 period following its current three-year pilot phase was already initiated by a GEF Participants' Meeting in April 1992,64 endorsed by Agenda 21 (paragraph 33.14), and is now under intergovernmental negotiation.

- an independent, non-governmental Earth Council has been established with headquarters in San José (Costa Rica). ${ }^{65}$ One of the declared objectives of the Council is to become a focal point for NGO cooperation in UNCED follow-up; some have already compared its potential "watchdog" role to that of Amnesty International.65 Together with other nongovernmental bodies established during UNCED preparations and continuing in operation (such as the Genevabased Business Council for Sustainable Development), ${ }^{67}$ the Earth Council illustrates the widening scope of NGO participation in the post-Rio period.

Among other new actors scheduled to make their debut on the global scene during that period are the Conferences of Parties to the two Rio conventions. The potential for "inter-treaty conflicts" in this field is growing, not only vis-à-vis existing tradedriven agreements, ${ }^{68}$ but also between different environmental

o4 See Global Environment Facitty: The Phot Phase and Beyond (GeF Working Paper No. 1, May 1992); and GEF, Report by the Chairman to the December 1992 Participants' Meeting (November 1992) at 23-26.

os Joint Press Release by Costa Rican President Rafael Angel Calderón and Maurice Strong, San José, September 3, 1992; and Earth Council New Release, Washington DC, October 8, 1992. See also Agenda 21, paragraph 38.45.

o P.M. Haas, M.A. Levy \& E.A. Parsons (note 3 above), p. 31.

67 See S. Schmidhenny, Changng Course: A Globai Business Perspective on Development and the Environment (Cambridge/Mass: MIT Press 1992); and The Business Council for Sustainable Development: Phase Two?, Network No. 21 (Geneva: Centre for Our Common Future, November 1992), 12. Also following the Rio Conference, the International Chamber of Commerce (ICC) established a "World Industry Council for the Environment" (headquartered in Paris), absorbing the former ICC International Environmental Bureau.

68 See Agenda 21, paragraph 39.3(g); see also note 55 above, and J. Cameron \& J. Robinson, The Use of Trade Provisions in International Environmental Agreements and Their Compatibility with the GATT, 2 Y.B.INT'L ENv. L. 3-30 (1991); K.G. Beacham, International Trade and the Environment: Implications of the General Agreement on Tariffs and Trade for the Future of Environmental Protection Efforts, 3 Co. 
instruments and their governing bodies competing for normative authority. ${ }^{69}$ While UNCED brought no basic changes in the mechanisms of international law-making or dispute resolution, it focused attention on the implementation and "effectiveness" of existing environmental conventions, ${ }^{70}$ including the need for progress reports to the new Commission from the Conferences of Parties." Another significant shift of emphasis prominently reflected in chapters 8 and 39 of Agenda 21 is the recognition of imbalances in treaty-making and treaty operation that had placed developing countries at a disadvantage in practice and therefore need to be redressed by remedial measures, including assistance, training and financial support in the course of treaty negotiation and implementation. ${ }^{72}$

The Rio Conference may have succeeded in averting-or at least postponing-a North-South showdown, the head-on confrontation between developed and developing countries which many had predicted. ${ }^{73}$ What it could not avoid or defer was a trend towards further polarization, manifested not only in the constant balancing (based on parity or alternation) of "Northern" and "Southern" positions on everything from meeting

J. INT'l ENv. L. \& PoI'y 655-682 (1992); and J.H. Jackson, World Trade Rules and Environmental Policies: Congruence or Conflict?, 49 WAS. \& LeE L. REv. 1227-1278 (1992).

os E.g., according to the principles for restructuring the Global Environment Facility (GEF), as agreed in April 1992 (note 64 above), an intergovernmental Participants' Assembly is to "direct the utilization of GEF funds". Yet, when the Climate Change and Biodiversity Conventions designated the GEF to operate their interim "financial mechanism", they also provided that it shall function "under the guidance" (Article 11, Climate Change Convention) or "under the authority and guidance" (Article 21, Biodiversity Convention) of the respective intergovernmental Conferences of the Parties to these conventions.

7o See Agenda 21, paragraph 39.8, and the 1992 UNEP Programme (note 13 above); see also UNCED Doc. A/CONF.151/PC/103 (January 1992), and the collected UNCED Research Papers in The Effectiveness of International Environmental. AGreements (P.H. Sand ed., Cambridge/UK: Grotius Publications, 1992), 539 pp.

" UNGA Resolution 47/191 (note 62 above), paragraph 3(h); see generally K. Sachariew, Promoting Compliance with International Environmental Standards: Reflections on Monitoring and Reporting Mechanisms, 2 Y.B. INT'L ENv. L. 31 (1991); J.H. Ausubel \& D.G. Victor, Verification of International Environmental Agreements, 17 Annual Rev. Eneroy EnViron. 1.43 (1992).

7 Agenda 21, paragraphs 8.15, 8.22, 39.1(c) and 39.9; see also the examples of imbalance given in UNCED Doc. A/CONF.151/PC/103 (note 70 above), paragraphs 12-16.

${ }^{73}$ See the remarks by G. Biggs, Issues Relating to the 1992 Brazil Conference on the Environment, [1992] ASIL, Proceedinas 401, emphasizing the spirit of cooperation that prevailed in PrepCom debates. See also Speth and Brock (note 3 above). 
venues and committee chairmen to agenda priorities, ${ }^{74}$ but also in a distinct new bipolar pattern of negotiating and decisionmaking procedures. As an illustration, when the drafting group for the Rio Declaration reached an impasse during PrepCom 4, the negotiators desperately called for a meeting room more conducive to consensus than the usual UN conference halls which are either auditorium-shaped or symmetrically arranged for delegations opposing each other. The only room with a perfect round table, and the one ultimately selected for that reason, was Conference Room 8. When delegations arrived, however, the "Group of 77" immediately insisted that exactly one half of the circle be occupied by representatives of developing countries, while all other delegations were to sit along the other half, with the chairman (agreed to alternate for each session, North after South) seated at the intersection. ${ }^{75}$ That configuration of symmetric semicircles prevailed throughout the series of night sessions which followed, until the group ran into terminal deadlock, ultimately to be salvaged by direct intervention of PrepCom chairman Tommy Koh. ${ }^{76}$

The "semicircles syndrome" appears to have become symptomatic of contemporary multilateral negotiations. In the environmental context, the model most frequently cited now is the Executive Committee of the Montreal Protocol's Multilateral Fund, established on an interim basis at the 1990 London conference ${ }^{77}$ and reconfirmed as a permanent institution at the 1992 Copenhagen conference: ${ }^{78}$ the Committee consists of 7 representatives of developing countries and 7 from "other" countries, with the chairmanship alternating annually between both

74 In a typical, though unsuccessful move in the Rio Main Committee negotiations, the European Community tried to trade off "Northern" agreement to a future Desertification Convention (note 47 above) against "Southern" agreement to a Forest Convention.

75 The delegates of the Russian Federation and other former "Eastern" countries grudgingly accepted to be seated with the "Northern" semicircle. The delegate of the Vatican (who had a major stake in the negotiations because of the population issue in principle 8) chose to sit at the other intersection, across from the chairman, where North also met South.

${ }^{76}$ See the summary account by Mann (note 33 above), at 408 .

$n$ Amendments to Article 10 of the 1987 Montreal Protocol on Substances that Deplete the Ozone Layer, paragraph 5, and Appendix II to Decision II/8 of the London Conference; text in 30 I.L.M. 537 (1991) and UNEP, HANDBOOK FOR THE MONTREAI Protocol on Substances that Deplete the Ozone Layer 98.99 (1991).

${ }^{78}$ Fourth meeting of the Conference of the Parties to the Montreal Protocol (Copenhagen, November 23-26, 1992), decision IV/17. 
groups. Although there are earlier examples of bipolar systems of governance-e.g., the balance of producing and consuming countries established in international commodity agreements, such as the 1983 International Tropical Timber Agreement ${ }^{79}$-the Montreal Protocol was first in drawing the line explicitly between developing countries and others, ${ }^{80}$ corresponding to what Gus Speth has called the new North-South "axis of world affairs" confirmed by the Earth Summit. ${ }^{81}$

The closest analogy to this bipolar regime is of course the ritual balance formerly maintained in East-West relations, most typically reflected in the governance system of multilateral agreements under the auspices of the UN Economic Commission for Europe. ${ }^{82}$ The major difference, however, is that the post-Rio North-South semicircles are mutually exclusive and allow no third segment, no neutral or "non-aligned" group. While countries may de facto "graduate" from the status of developing countries, ${ }^{83}$ or may in turn drop below the $\$ 4,465$ threshold of annual per capita income, there is no non-alignment option: poverty rarely is a matter of choice-tertium non datur.

79 Article 10 of the Agreement allocates equal numbers of votes to producing and consuming members; text in UNEP, Selected Multilateral Treaties in the Field of THE ENVIRONMENT, vol. 2 (note 10 above) at 274.

so The status of "Parties operating under paragraph 1 of Article 5" (which in turn requires "developing country" status, i.e. a Southern list) is determined by the Conference of the Parties, normally on the basis of a country's entitlement to UN technical assistance; see Decision I/12 (E) of the First Meeting of the Conference of the Parties (Helsinki, 1989), and Decision IV/7 of the Fourth Meeting (Copenhagen, 1992). The 1992 Climate Change Convention carried the differentiation process a step further by annexing a Northern list ("developed country Parties and other Parties") to the treaty text.

" Note 3 above at 146.

*2 The UN/ECE model (which included elaborate, though mostly unwritten, "caucus" rules) has actually been suggested as a model for global environmental governance; see E.M. Chossudovsky, East-West Diplomacr for Environment in the Untred Nations (Geneva: United Nations Institute for Training and Research, 1988); and E.M. Chossudovsky, The High-level Meeting within the Framework of the ECE on the Protection of the Environment: A New Model for 'East-West" Co-operation Through Conference Diplomacy?, The United Nations System at Geneva: Scope and Practices of Multilateral Diplomacy and Co-operation 355-349 (M.A. Boisard \& E.M. Chossudovsky eds., Geneva: United Nations Institute for Research and Training, 1992).

${ }^{8}$ In the World Bank, when a borrowing member country reaches a certain level of per capita GNP (currently $\$ 4,465$ ), a review is made to phase out and ultimately end Bank lending; attainment of the GNP threshold does, however, not automatically terminate a country's entitlement status (which also applies to the Global Environment Facility, note 63 above). 


\section{CONCLUSIONS}

The Rio Conference did not usher in the "New International Ecological Order" many had hoped for, ${ }^{84}$ nor was it probably a "turning point in the history of civilization." 85 But then-a propos historical comparisons-neither was any other diplomatic conference over the past two centuries or so, including the two largest ones (Vienna 1815 and Versailles 1919) invoked in my introduction.

Yet as regards international environmental law, UNCED's prospects of success may well be more promising. Curiously, both the Vienna and the Versailles Conferences left a more durable legacy in this particular field than with regard to their primary political targets: The one lasting accomplishment of the 1815 Vienna Congress was the system of international watercourse agreements which it mandated for Europe ${ }^{86}$ and which to this date provides the legal basis, e.g., of the current Regulations for the Carriage of Dangerous Substances on the Rhine River (ADNR). ${ }^{87}$ Similarly, it was the 1919 Versailles Conference which established the ILO system of international labour conventions, ${ }^{88}$ resulting in the first global ban on a toxic chemical, the 1921 Convention Concerning the Use of White Lead in Painting still in force today ${ }^{89}$ If the legal instruments emanating from Rio turn out to be as robust as that, UNCED will have been worth the effort.

\footnotetext{
84 Pronk (note 44 above).

${ }^{\text {as }}$ As suggested in the Earth Summit speech by the President of Nauru, quoted by Yost (note 8 above).

so See Article 108 et seq. and Annex 16(B) of the Vienna Final Act of June 9, 1815 (2 Martens N.R. 361); see F. Meissner, Rhine River, in: 12 ENCYClopedia of Public International Law 310-316 (R. Bernhardt ed., 1990).

87 Adopted by the Central Rhine Navigation Commission on April 29, 1970, pursuant to the Revised Convention on the Navigation on the Rhine (Mannheim, October 17, 1868, as amended at Strasbourg on November 20, 1963). The Central Commission was initially established in 1831 , in response to the recommendations of the Vienna Congress. See J.G. Lammers, International Cooperation for the Protection of the Waters of the Rhine Basin Against Pollution, 5 Nethertands Y.B. INT'L L. 59-110 (1974), at 98-101.

89 In Part XIII of the treaty; see E. von Puttkamer, Versailles Peace Treaty (1919), 4 Encyclopedia of Public International Law 276-282 (R. Bernhardt ed., 1980); and A. Alcock, Historiy of International Labour organization (1971).

${ }^{89}$ See the UNEP RegtsTer OF TREATIES (note 9 above), p. 1 . On the ILO experience with conventions to protect the working environment (including the more recent 1990 Convention concerning Safety in the Use of Chemicals at Work) see V.A. Leary, Working Environment, in: The Efpectiveness of INTERnational EnvironmentaI AGREEMENTS (note 70 above), at 362-391.
} 
Meanwhile, there is at least one area where the Rio Conference has already left its imprint on the evolution of environmental law-by formally anointing the concept of "sustainable development" for legal use. I still remember the malicious comment by the Brazilian delegate to the UNCED Preparatory Committee, my good friend Pedro Motta Pinto Coelho (Director of Environment in the Ministry of Foreign Affairs and political scientist by training), after he persuaded Working Group III to change the term "international environmental law" to read "international law of sustainable development" throughout the text of Agenda 21: "That will keep you lawyers busy well into the 21 st century." Judging from the enthusiastic response of the legal profession, ${ }^{90}$ he may be right after all.

90 The International Law Association has established a new Committee on Legal Aspects of Sustainable Development. The Foundation for International Environmental Law and Development has scheduled a consultation on "Sustainable Development: The Challenge to International Law" to be held at Windsor Castle on April 27-29, 1993. 